\title{
The Study on Activation Strategy of Time-honored Brand
}

\author{
Jiankang Mu \\ Business School, Sias International University, Henan, China \\ Corresponding author: author@e-mail.org
}

\begin{abstract}
Time-honored brands have profound cultural heritage, a large part of glorious timehonored brands has gradually disappeared from the market. Brand activation is the core of management strategic of brand equity as well as the fundamental requirement of time-honored enterprise recovery. This paper constructs the time-honored brand purchase model and finds that consumers nostalgic psychology for the consumer's perception and buying behavior has a positive effect.
\end{abstract}

\section{Instuduction}

Time-honored brand refers to the brand management has a long history, with generations of products, production techniques or services have a distinct Chinese traditional culture. They were founded before 1956, achieved wide recognition of society, have a good reputation.

With the development of economic globalization, more and more foreign brands poured into China. Because of the lack of brand consciousness and core competitiveness, China's time-honored brand enterprises encountered hard-hit and difficult to continue development. Part of the old brand market share has fallen sharply, even withdraw from the market. China's time-honored brand enterprises face enormous survival crisis.

\section{2 literature review}

\subsection{Time-honored brand}

Brand is a name, term, mark, symbol or design, or their mutual combination, it is a product or service used to identify a consumer or a group of consumer. It makes different with competitors' products or services. Brand is a kind of intangible assets, brand owners can get competitive advantage and huge economic benefits from it. According to the needs of article research, we choose Time-honored brand as the object of this research. To be specific, these Timehonored brands must have the following typical characteristics: 1)With long historical period; 2)Distinctive national character; 3)With the reputation of social recognition; 4) An ongoing philosophy of culture; 5)With the traditional process of high quality.

\subsection{Consumers nostalgic}

Nostalgia is a kind of preferences (for people, places or things), it's a kind of good feelings. These things are common in younger. Brand activation based on consumers' nostalgia is a common strategy in western countries when solve the problem of aging brands. They use nostalgic psychology of consumers and stimulate consumers nostalgia, eventually led to purchases.

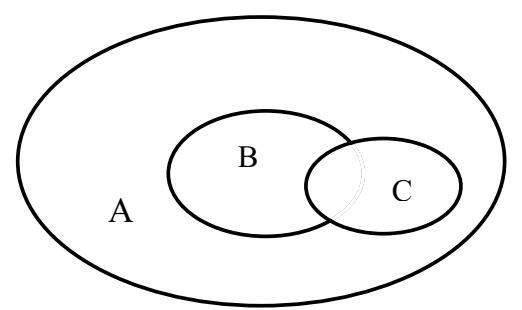

Fig.1. Time-honored brand relationship diagram. 
A:Time-honored brand $\quad$ B: Time-honored brand of China $\quad$ C:Time-honored brand of Chinese

\section{Theoretical framework}

\subsection{Theoretical model}

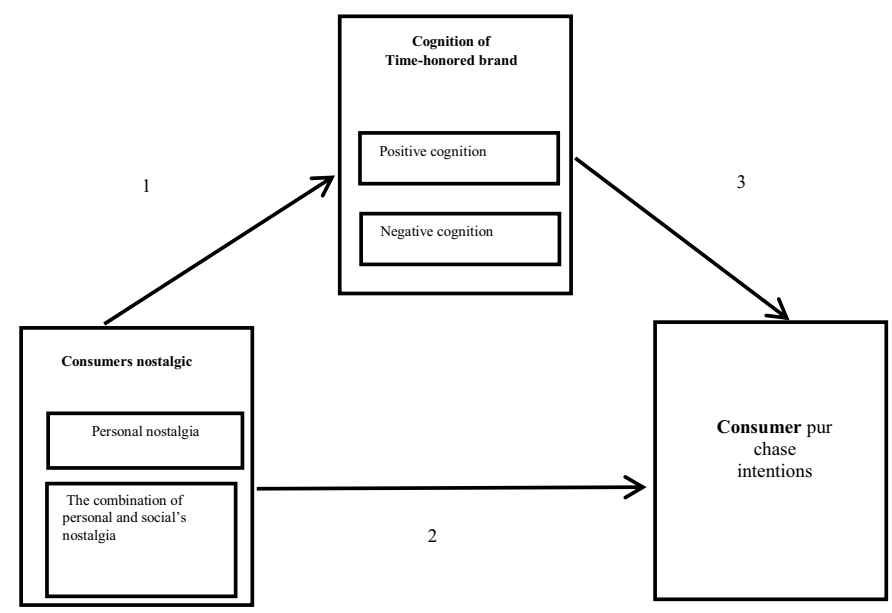

Fig.2. Time-honored brand purchase behaviour.

\subsection{Research Model}

Place the figure as close as possible after the point where it is first referenced in the text. If there is a large number of figures and tables it might be necessary to place some before their text citation. If a figure or table is too large to fit into one column, it can be centred across both columns at the top or the bottom of the page.

Based on two groups of consumers score, we judge the relationship between consumer nostalgia and consumerawareness.We put forward these assumptions as follows:

H1a: "Consumer nostalgia" to "Positive Consumer Cognition of Time-honored brand" has a positive effect.

H1b: "The combination of personal and social's nostalgia" to "Positive Consumer Cognition of Time-honored brand" has a positive effect.

H1c: "Personal nostalgia" to "Negative Consumer cognition of Time-honored brand" has a positive effect.

H1d: "The combination of personal and social's nostalgia" to "Negative Consumer cognition of Time-honored brand" has a positive effect.

Due to the nostalgia on consumers purchase intentions of consumers to be able to make a difference has been confirmed by numerous studies, we put forward these assumptions as follows:

H2a: "Personal nostalgia" to "Consumer purchase intentions" has a positive effect.

$\mathrm{H} 2 \mathrm{~b}$ : "The combination of personal and social's nostalgia" to "Consumer purchase intentions" has a positive effect.

Consumer cognition of Time-honored brand can has an impact on Consumer purchase intentions. So we put forward these assumptions as follows:

H3a: "Positive Consumer Cognition of Time-honored brand" to "Consumer purchase intentions" has a positive effect.

H3b: "Negative Consumer cognition of Time-honored brand" to "Consumer purchase intentions" has a positive effect.

\section{Empirical study}

\subsection{Case selection}

Here is an example of the Pechoin. Founded in 1931, the company is a research, development, production, sales and service as one of the professional of cosmetics. With 80 years of history, Pechoin is one of China's first cosmetics brands, and its products are not only affordable, but also well received by consumers, such as Vaseline cream, body lotion and others. As domestic cosmetics pioneer, Pechoin is different from other domestic cosmetics manufacturers in the product category, product packaging, and brand image. The corporation has a higher distinction degree because of grasping the herbal essence series primarily for Chinese female characteristics and preferences. 


\subsection{Questionnaire design and data collection}

Table 1. Descriptive statistical analysis.

\begin{tabular}{|c|c|c|c|}
\hline $\begin{array}{l}\text { Basic } \\
\text { situation }\end{array}$ & Classification & Number & $\begin{array}{l}\text { Effective } \\
\text { percentage }\end{array}$ \\
\hline \multirow{6}{*}{ Age } & Under 20 & 1 & 1.1 \\
\hline & $21-30$ & 59 & 64.8 \\
\hline & $31-40$ & 22 & 24.2 \\
\hline & $41-50$ & 5 & 5.0 \\
\hline & $51-60$ & 3 & 3.3 \\
\hline & Over 60 & 1 & 1.1 \\
\hline \multirow{4}{*}{ Qualifications } & $\begin{array}{l}\text { Under Junior High } \\
\text { School }\end{array}$ & 4 & 4.4 \\
\hline & $\begin{array}{l}\text { Senior high school, } \\
\text { Technical secondary } \\
\text { school }\end{array}$ & 30 & 33 \\
\hline & $\begin{array}{l}\text { Junior college, } \\
\text { Undergraduate course }\end{array}$ & 50 & 55 \\
\hline & Over postgraduate & 7 & 7.6 \\
\hline \multirow{4}{*}{$\begin{array}{l}\text { Monthly } \\
\text { income }\end{array}$} & Under 2000 & 11 & 12 \\
\hline & $2000-5000$ & 50 & 55 \\
\hline & $5000-10000$ & 28 & 30.8 \\
\hline & Over 10000 & 2 & 2.2 \\
\hline
\end{tabular}

As can be shown from the diagram, respondents were concentrated in the 21-40 years of age, besides less than 20 years old and over the age of 40 respondents were only $11 \%$. It has a larger relationship with the paper selected case. Women, who age from 21 to 40 years old, are the main consumers of cosmetics such products. Therefore, the samples of age at this stage is a relatively regular phenomenon. In another, the level of education of these respondents are mainly at a high school, secondary school, college or university. This phenomenon in general is also very compatible with current consumers. The monthly income of these people is concentrated in 2000 to 10000 , which reaches $85.8 \%$ percent of the sample. And this conclusion is more in line with the actual situation of the general consumers.

\section{Data analysis}

\subsection{Reliability analysis}

Reliability refers to credibility of the test. Reliability is a credibility indicator of evaluating respondents filling in the questionnaire data.

Table 2. Reliability statistics.

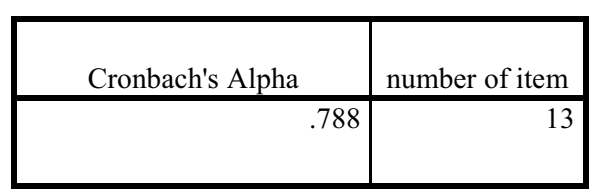

Alpha coefficient in $0.65-0.7$ as the minimum acceptab-le values, $0.7-0.8$ is very good, $0.8-0.9$ is extremely good. From the table above, in this paper, scale reliability is 0.788 , the Scale reliability in this paper is very high.

\subsection{Correlation analysis}

According to last figure, the correlation coefficient of personal nostalgia to positive consumer cognition of Timehonored brand, error is less than 0.01 , within $99 \%$ confidence interval correlation, the correlation coefficient is 0.831 , it is a significant positive correlation, we can preliminary validate the existence of H1a.

The combination of personal and social's nostalgia to positive consumer cognition of Time-honored brand, within $95 \%$ confidence interval correlation, the correlation coefficient is -0.293 . So there is a negative correlation relationship between the combination of personal and social's nostalgia to positive consumer cognition of Time-honored brand. What's more, personal nostalgia to negative consumer cognition of Time-honored brand, error is 0.0137 , the correlation 
coefficient is negative, so there is a negative correlation relations-hip between them. The correlation coefficient of personal nostalgia to positive consumer cognition of Time-honored brand is 0.809 , error is less than 0.01 .

Table 3. Correlation analysis.

\begin{tabular}{|l|l|l|l|}
\hline \multicolumn{2}{|c|}{} & Positive & Negative \\
\hline \multirow{2}{*}{$\begin{array}{l}\text { Personal } \\
\text { nostalgia }\end{array}$} & $\begin{array}{l}\text { Pearson } \\
\text { correlation }\end{array}$ & $0.831^{* *}$ & $-0.20^{*}$ \\
\cline { 2 - 4 } & Significant & 0.000 & 0.0137 \\
\cline { 2 - 4 } & $\mathrm{N}$ & 91 & 91 \\
\hline $\begin{array}{l}\text { The } \\
\text { combination } \\
\text { of personal } \\
\text { and social's } \\
\text { nostalgia }\end{array}$ & $\begin{array}{l}\text { Pearson } \\
\text { correlation }\end{array}$ & $-0.293^{*}$ & $0.809^{* *}$ \\
\cline { 2 - 4 } & Significant & 0.005 & 0.000 \\
\hline
\end{tabular}

Personal nostalgia to positive consumer cognition of Time-honored brand has a positive effect, we can preliminary validate the existence of the hypothes H1d.

According to last figure, perason correlation is 0.375 , within $99 \%$ confidence interval correlation. So positive consumer cognition of Time-honored brand to consumer purchase intentions has a significant positive correlation. We can preliminary validate the existence of the hypothes $\mathrm{H} 3 \mathrm{a}$.

The correlation coefficient of negative consumer cognition of Time-honored brand to consumer purchase intentionsis -0.293 , within $95 \%$ confidence interval correlation. So there is a negative correlation relationship between them.

Table 4. Correlation analysis (Purchase intentions).

\begin{tabular}{|l|l|l|}
\hline \multicolumn{2}{|c|}{} & $\begin{array}{l}\text { Purchase } \\
\text { intentions }\end{array}$ \\
\hline \multirow{2}{*}{$\begin{array}{l}\text { Personal } \\
\text { nostalgia }\end{array}$} & $\begin{array}{l}\text { Pearson } \\
\text { correlation }\end{array}$ & $0.316^{* *}$ \\
\cline { 2 - 3 } & Significant & 0.040 \\
\cline { 2 - 3 } & $\mathrm{N}$ & 91 \\
\hline $\begin{array}{l}\text { The } \\
\text { combination } \\
\text { of personal } \\
\text { and social's } \\
\text { nostalgia }\end{array}$ & $\begin{array}{l}\text { Pearson } \\
\text { correlation }\end{array}$ & $-0.26^{*}$ \\
\cline { 2 - 3 } & Significant & 0.05 \\
\hline
\end{tabular}

According to last table, the correlation coefficient of personal nostalgia to consumer purchase intentions is 0.316 , within $95 \%$ confidence interval correlation. So personal nostalgia to consumer purchase intentions is a significant positive correlation. We can preliminary validate the existence of the hypothes H2a. The correlation coefficient of the combination of personal and social's nostalgia to consumer purchase intentionsis -0.26 , there is a negative correlation relationship.

Table5. Correlation analysis.

\begin{tabular}{|l|l|r|}
\hline \multicolumn{2}{|c|}{} & \multicolumn{1}{|c|}{$\begin{array}{c}\text { Purchase } \\
\text { intentions }\end{array}$} \\
\hline $\begin{array}{l}\text { Positive } \\
\text { cognition }\end{array}$ & Pearson correlation & $0.375^{* *}$ \\
\cline { 2 - 3 } & Significant & 0.001 \\
\cline { 2 - 3 } & N & 91 \\
\hline \multirow{2}{*}{$\begin{array}{l}\text { Negative } \\
\text { cognition }\end{array}$} & Pearson correlation & $-0.293^{*}$ \\
\cline { 2 - 3 } & Significant & 0.04 \\
\cline { 2 - 3 } & N & 91 \\
\hline
\end{tabular}

\section{Recommendation}


Opinions vary on this point. Because of the products, services, history, culture and many other aspects are different, the brand activation strategy is also different. Combined with the actual situation of the brand development, starting from the research direction of this article, the process of Pechoin's brand activation should pay more attention to purchase intentions.

\subsection{Make use of the nostalgic psychology contributing to purchase behavior}

The Pechoin was founded in 1931, is one of the earliest cosmetics brand in China, it has more than eighty years old so far, And in the 1960s, create a monopoly in the market. So we can learn that the Pechoin was very popular to consumers at the time. Therefore, for the Pechoin's situation at present, this paper argues that we can make use of the nostalgic psychology contributing to purchase behavior of consumers. First of all, for the former customers, Pechoin can make the products they were familiar with, such as pearl cream, glycerin, cheap and fine old products, to attract the customers to buy them again. Second, for the customers who never buy this brand, due to the elders and nostalgic psychology drives around, they will produce high evaluation and expectations of Pechoin. In the process of marketing should be paid attention to the counter display, advertising campaign, product packaging, Marketing staff and other ways to Transfer memories of the past. For example, make the boutique brand productionas same as the past, play old songs in store and in addition to show the products, they can add some old items for the consumer to create a nostalgic shopping environment. Finally, in view of the consumers have never heard of the Pechoin, should help them know the brand from the old identity of the Pechoin, let consumers know about it as much as possible of the current information, one of the most important part is hidden behind the brand of history and legend. To arise the attention of consumers, and translate this into buying power.

\subsection{Distinguishing standards for each segmentation of the market marketing plan}

When making marketing plan should be targeted. And according to different age, different degree of consumer's nostalgia emotions is also different, the same plan for all consumers would be unwise to marketing. In simple terms, aim at young consumers, they prefer to purchase cosmetics on the Internet, but the Pechoin in the online sales model is not mature. The design of the web pages need to improve, the display of store if couldn't arise consumer's nostalgic psychology, the Pechoin will the same as other general brands. So, increase the element of nostalgia in web designment to attract the attention of consumers is very important.

\subsection{Stimulate consumers to accept the culture and emotion recognition of the time-honored}

Largely, the time-honored brand is different from general brands .For one thing, the old brand has a rich cultural heritage .For another, it gained a good reputation in the process of long-term development, such as Pechoin, which has more than 80 years of history. In the 1930s, Pechoin's skin care products sold well and became the first cosmetic choice of the celebrities. Ruan lingyu, Zhou Xuan and other international stars led the youth of an era, with the unique scent of Pechoin. Even the Song sisters, wandering in Shanghai that year, also respected the products of Pechoin among the United Kingdom, Germany, France and other diplomatic envoys to China. To some extent, they felt that the brand contained the Oriental fashion. Only mentioned in the advertisement, or marked on the product packaging are not enough. To make sure a consumer to remember this story, we must strengthen the impression of this information in the consumer's mind. Here are some ways: First of all, the corporation can sponsor the related TV series, which appear the actors using its product shots. In order to attract consumers ' attention, the company can also cooperate in the development and sale of actual products, launching consistent with the historic porcelain-cans cosmetics. If the marketing budget allows, the sponsorship of such television or movies can be increased in the promotion of the brand. Secondly, it can directly add some elements which represent the Republic of China era to the ad plot design. The plot may contains a certain story so that the ad content is more plentiful and different from the general advertising of cosmetics, which only emphasize product efficiency .

\section{References}

1. Keller, K.L.. Managing Brands for the Long Run: Brand Reinforcement and Revitalization Strategies. California Management Review(2004).

2. Brown, S., R.V. Kozinets, and J.F. Sherry. Teaching Old Brands New Tricks: Retro Branding and the Revival of Brand Meaning. Journal of Marketing(2003).

3. Torelli, Carlos. Iconic brands and iconic categories: Consequences for the use of the cultural knowledge in judgments about foreign brands. Working Paper, University of Illinois(2009).

4. Holbrook, Morris B, and Robert M Schindler. Echoes of the dear departed part: some work in progress on nostalgia. Advances in Consumer Reshearch(1991).

5. Reisenwitz, Timothy H. Rajesh lyer, and Bob culter. Nostalgis advertising and the influence of nostalgia proneness. The Markrting Management Journal(2004). 